УдК $616.31-089.444$

DOI 10.11603/2411-1597.2019.2.10192

\title{
ОСНОВНІ ШЛЯХИ СТАНОВЛЕННЯ І РОЗВИТКУ СІМЕЙНОЇ МЕДИЦИНИ В УКРАЇНІ ЯК ОСНОВА РЕОРГАНІЗАЦІЇ ПЕРВИННОЇ МЕДИКО-САНІТАРНОЇ ДОПОМОГИ НАСЕЛЕННЮ
}

\author{
О. Г. Яковлева \\ Комунальне некомерційне підприємство \\ "Сєвєродонецький центр первинної медико-санітарної допомоги"
}

У статті проаналізовано поширеність професії лікаря загальної лікарської практики - сімейної медицини, яка є унікальною спеціальністю, орієнтованою на вирішення проблем пацієнта як особистості в контексті його сімейних і соціальних відносин. Вона вимагає широкого кола знань і вмінь, що включають як навички організації та управління діяльністю, так і консультування пацієнтів із різними проблемами, в тому числі й соціальними.

\section{MAIN WAYS OF FORMATION AND DEVELOPMENT OF FAMILY MEDICINE IN UKRAINE AS THE BASIS OF REORGANIZATION OF PRIMARY MEDICAL AND SANITARY AID FOR POPULATION}

\author{
O. G. Yakovleva \\ Municipal non-profit enterprise "Severodonetsk Center of Primary Health-care"
}

The article deals with the prevalence of the profession of general practice and family medicine, which is a unique specialty, focused on solving problems of patients as an individual in the context of family and social relationships. It requires a wide range of knowledge and skills, includes both skills of organization and management, as well as counseling of patients with various problems, including social ones.

Вступ. Кризова ситуація, у якій сьогодні функціонує охорона здоров'я, пов'язана з відсутністю адекватного фінансування й економічних важелів управління. При цьому коштів на підтримку і збереження наявної мережі лікувально-профілактичних закладів недостатньо, водночас відсутні належні заходи з розвитку ресурсозберігаючих технологій, створення більш економічної моделі надання медичної допомоги населенню. Даний процес зумовив необхідність реформування системи охорони здоров'я, що проводиться з метою забезпечення населення якісною медичною допомогою [1].

Одним із найважливіших завдань системи охорони здоров'я, особливо сільського населення, на сучасному етапі розвитку $є$ пошук оптимального співвідношення процесів спеціалізації та інтеграції. Реформування первинної медико-санітарної допомоги за принципом загальної лікарської практики значною мірою індукує зміни в наданні не тільки ам-

(с) О. Г. Яковлєва, 2019 булаторно-поліклінічної, а і невідкладної, і стаціонарної медичної допомоги населенню. При організації первинної медико-санітарної допомоги сільському населенню та визначенні оптимальної участі в ній лікарів різних спеціальностей насамперед виникає необхідність раціоналізації структурного співвідношення в роботі лікаря загальної практики й інших фахівців позалікарняної, швидкої та невідкладної, стаціонарної допомоги [2].

Відсутність комплексних соціально-гігієнічних досліджень проблем організації первинної медикосанітарної допомоги населенню, у тому числі за принципом роботи лікаря загальної практики, зумовило актуальність, наукову та практичну значущість цього дослідження. У зв'язку з тим, що близько 80 \% населення розпочинає та завершує обстеження і лікування в рамках первинної ланки системи охорони здоров'я, пріоритетним напрямком реформи охорони здоров'я $\epsilon$ розвиток і вдосконалення первинної медико-санітарної допомоги, від стану якої залежать ефективність

16 ISSN 2411-1597. МЕДСЕСТРИНСТВО. 2019. № 2 
і якість роботи всієї системи охорони здоров'я, а також розв'язання більшості медико-соціальних проблем.

Багаторічна орієнтація амбулаторно-поліклінічного обслуговування на його диференціацію і спеціалізацію стала причиною створення досить складної системи позалікарняної допомоги і виявила низку негативних явищ, які призвели до високого рівня госпіталізації населення, численних звернень до фахівців станції швидкої медичної допомоги і лікарів - вузьких спеціалістів.

Зміщення акценту з лікарняної на позалікарняну допомогу $є$ об'єктивною закономірністю розвитку охорони здоров'я в усьому світі. При цьому вдосконалення первинної медико-санітарної допомоги як у нашій країні, так і за кордоном нині й в перспективі пов'язано із введенням інституту лікаря загальної практики, який $\epsilon$ ключовою ланкою загальної лікарської сімейної практики. Процес переходу первинної ланки охорони здоров'я на принципи загальної лікарської сімейної практики пов'язаний зі складністю і багатоаспектністю. Мало уваги в існуючій літературі приділяють організаційним питанням сімейної медицини як системи та практично відсутні роботи, присвячені розв'язанню проблеми організаційного та інформаційного забезпечення територіальної системи загальної лікарської практики на основі системного аналізу [3].

Мета дослідження - розробка й обґрунтування структурно-організаційної моделі та алгоритму надання первинної медико-санітарної допомоги населенню на основі комплексного соціально-гігієнічного дослідження.

Основна частина. Виконано аналіз наукової літератури за останні десятиліття, у тому числі інтернет-ресурсів, з подальшим аналізом отриманих результатів.

Загальна лікарська практика є сукупністю різнорідних суб'єктів охорони здоров'я, взаємопов'язаних між собою і об'єднаних в одне ціле для якісного та своєчасного забезпечення населення країни первинною медико-санітарною допомогою, наданою лікарями загальної практики (сімейними лікарями), а також усіх видів діяльності у галузі загальної лікарської практики. Розвиток системи загальної лікарської практики істотно залежить від організаційного, інформаційного, матеріально-технічного, фінансового забезпечення. Недостатній рівень кожного з цих видів забезпечення в нових економічних умовах призводить до зниження якості медичної допомоги населенню [4].

Під організаційним забезпеченням системи загальної лікарської практики розуміють комплекс організаційно-керуючих заходів, спрямованих на забезпе- чення функціонування загальної лікарської практики як системи, управління їі ресурсним потенціалом і створення умов, при яких кожний громадянин перебуває під постійним і тривалим наглядом одного сімейного лікаря, який надає первинну медико-санітарну допомогу за основними видами захворювань і за необхідності залучає відповідних лікарів - фахівців у певних галузях медицини. На цьому етапі розвитку в системі охорони здоров'я у цілому, і в системі загальної лікарської практики зокрема, фактично відсутні єдині методологія, технічна та технологічна політика розробки, створення і впровадження інформаційних технологій, що призводить до зниження ефективності проведених в охороні здоров'я заходів. Внаслідок цього вся система охорони здоров'я із проведення комплексу профілактичних заходів, спрямована на здоров'я, працює недостатньо ефективно.

Первинна медико-санітарна допомога в Україні вирішує таке коло питань: діагностика і лікування хворих на найпоширеніші захворювання; доліковування хворих після отримання медичної допомоги на вторинному та третинному рівнях; цільове направлення хворих до спеціалізованих або високоспеціалізованих закладів для отримання медичної допомоги у випадках, які виходять за межі компетенції лікарів закладу первинної медико-санітарної допомоги; проведення комплексу профілактичних заходів, спрямованих на формування, збереження і зміцнення здоров'я здорових людей; диспансеризація хворих і здорових людей з орієнтацією на донозологічну та ранню нозологічну діагностику, а також медико-соціальну профілактику; надання невідкладної медичної допомоги [5].

Аналіз звернень населення за позалікарняною медичною допомогою виявив, що найчастіше звертались до лікарів (на 1000 жителів) таких спеціальностей (за низхідною): терапія, педіатрія, акушерство і гінекологія, офтальмологія, хірургія, оториноларингологія, неврологія, дерматовенерологія, фтизіатрія, психіатрія, наркологія. Високу функцію лікарської посади відзначають в офтальмологів, хірургів, оториноларингологів, дерматовенерологів і пояснюють дефіцитом лікарів цих спеціальностей у сільських районах. Навантаження лікарів у амбулаторно-поліклінічних закладах визначають кількістю відвідувань лікувального закладу, візитів лікаря додому і числом зайнятих посад. У системі охорони здоров'я в сільських регіонах навантаження лікаря на амбулаторному прийомі зазвичай досить високе.

Найбільше звернень жителів на 1000 населення, згідно з результатами аналізу наявної медичної до- 
кументації, зумовлені такими факторами: потенційна небезпека для здоров'я, пов'язана з неінфекційними хворобами; звернення у зв'язку з іншими обставинами; інфекційні хвороби; звернення через необхідність проведення специфічних процедур й отримання медичної допомоги [6].

Найменше звернень було з приводу потенційної небезпеки для здоров'я, пов'язаної з особистим або сімейним анамнезом і певними обставинами, що впливають на здоров'я; соціально-економічних та психосоціальних обставин; звернень через обставини, що стосуються репродуктивної функції.

Серед дітей (на 1000 дитячого населення) найбільше звернень було з приводу потенційної небезпеки для здоров'я, пов'язаної з неінфекційними хворобами; інфекційних хвороб; звернень через необхідність проведення специфічних процедур й отримання медичної допомоги [7].

Попит на послуги первинної медико-санітарної допомоги, як правило, оцінюють за кількістю амбулаторних контактів (відвідувань) на одну людину на рік. В Європейському регіоні середні значення цього показника становлять близько 7. У західноєвропейських країнах частота амбулаторних відвідувань коливається в межах 5-7, в Україні вона значно більша і становить 9-10 відвідувань на одного жителя на рік. Якщо із загальної кількості амбулаторних контактів виділити ті, які припадають на лікарів первинної ланки, то в кількісному вимірі попит на лікарські послуги первинного рівня виглядає досить 4-6 відвідувань (у розвинених європейських країнах - 90 \% від загальних амбулаторних контактів, в Україні близько 40-60 \%). Разом із тим, якісні характеристики первинної допомоги у цих групах країн істотно відрізняються, виходячи з того, хто є головною фігурою - лікар загальної практики (сімейний лікар) або фахівець терапевтичного профілю (дільничний терапевт або педіатр).

У різних країнах світу існують певні відмінності в організації роботи лікаря загальної практики - сімейного лікаря, зумовлені національними особливостями структури охорони здоров'я та системою оплати медичної допомоги. Принцип закріплення лікаря за населенням певної території в зарубіжних країнах називають географічним (комунальним, територіальним). Послуги лікарів у галузі первинної медико-санітарної допомоги надаються за географічним принципом у Болгарії, Угорщині, Ізраїлі, Ісландії, Іспанії, Литві, Норвегії, Польщі, Португалії, Румунії, Словаччині, Словенії, Фінляндії, Хорватії, Швеції. Головним аргументом прихильників закріплення громадян, які про- живають на певній території, за конкретним лікарем загальної практики є забезпечення можливості більш ефективної організації насамперед профілактичної та медико-соціальної роботи, коли населення, яке проживає у якомусь конкретному місці, обслуговується одним лікарем або групою лікарів [8].

До позитивних якостей територіально-дільничного принципу належить те, що при правильній його організації та застосуванні існує можливість забезпечити наближення медичної допомоги до місця проживання або роботи населення; тривалість (тривале спостереження населення одним і тим персоналом) і спадковість в обслуговуванні пацієнтів; можливість комплексного проведення профілактичних, лікувальних і реабілітаційних заходів, диспансерного спостереження. Проте застосування територіально-дільничного принципу супроводжується також і певними негативними моментами: обмеження прав споживача на свободу вибору; ігнорування потреб пацієнтів; відсутність конкуренції в медичному обслуговуванні; незацікавленість у залученні пацієнтів до вирішення питань щодо підтримки їхнього здоров'я [9].

Вільний вибір лікаря первинної ланки полягає в тому, що населення вибирає лікаря для постійного медичного обслуговування. Періодично, зазвичай один раз на рік. Але не частіше, ніж один раз на півроку, надається можливість змінити лікаря. Вибір оформляють документально шляхом запису особи або сім'і у список того чи іншого лікаря і це є своєрідним договором між пацієнтом і лікарем. Реалізація пацієнтом права вільного вибору фахівця, який надає первинну допомогу, характеризується низкою позитивних моментів, основні з них: підвищення уваги лікаря до проблем пацієнтів і створення умов для підвищення якості його роботи у зв'язку з залежністю лікаря від пацієнта; створення умов для встановлення довготривалих партнерських взаємовідносин із пацієнтами та родинного обслуговування; можливість контролю пацієнтом деяких елементів якості медичного обслуговування задоволеності населення; створення умов для відбору кваліфікованих фахівців первинної допомоги. Разом із тим, варто зазначити, що впровадження принципу вільного вибору лікаря спочатку може створити певні труднощі, до яких можна зарахувати: зростання витрат на проведення організаційних заходів; можливість нерівномірного навантаження лікарів первинної ланки. При переході від системи прикріплення пацієнтів до вільного вибору необхідно попередньо вжити низку заходів: роз'яснювальна, маркетингова кампанія з підготовки 
населення до нової системи, проведення приписної (реєстраційної) кампанії, організаційна підготовка.

При розробці організаційної системи первинної медико-санітарної допомоги потрібно враховувати такі показники: кількість населення, яку обслуговують; штатну чисельність; перелік видів медичної допомоги, нормативну документацію, контрольні показники роботи; етапність організації первинної медико-санітарної допомоги за принципом загальної лікарської практики; механізми фінансування; статеві коефіцієнти нормативу згідно з кількістю населення [10].

Для підвищення якості лікувальної роботи, надання висококваліфікованої допомоги вкрай необхідне корінне технічне переобладнання лікарень як пріоритетний розвиток охорони здоров'я. Укомплектування лікарень необхідною апаратурою (рентгенівською, фізіотерапевтичною, обладнанням для лабораторій) забезпечить впровадження об'єктивних методів дослідження, ранню діагностику захворювань і поліпшення лікувальної роботи.

Укрупнення стаціонарів лікувально-профілактичних установ, подальший розвиток процесів спеціалізації та інтеграції медичної допомоги не тільки значно розширили обсяг і діапазон діяльності лікарень, а й викликали появу нових і вдосконалення існуючих раніше організаційних форм їх роботи. Широкого розвитку набуло створення на базі великих багатопрофільних лікарень спеціалізованих центрів. Чимало авторів зазначали, що цей шлях сприяв більш раціональному використанню ліжкового фонду, оскільки він дозволяє забезпечити належну послідовність у роботі лікарів, значно поліпшити якість медичної допомоги, підвищити кваліфікацію фіхівців, домогтися істотного економічного, й особливо медичного ефекту [11].

Сімейна медицина при реалізації первинної медичної допомоги повинна вирішувати кілька основних завдань, зокрема забезпечення безперервності допомоги. Саме при формуванні довірчих відносин між лікарем і пацієнтом створюються унікальні умови для спостереження за перебігом хронічних захворювань, запобігання їх загостренню, використання методів вторинної профілактики й освітніх програм для пацієнтів і членів сім'ї, адже для реалізації алгоритму безперервності медичної допомоги об'єктом $\epsilon$ саме пацієнт, а не його захворювання. Всеосяжність медичної допомоги не означає, що лікар загальної практики може вилікувати пацієнта від будь-якого захворювання. Лікар може справитися з розв'язанням 90-95 \% проблем, з якими пацієнт до нього звернувся.
Дуже часто причини, що турбують пацієнта, лежать у площині психосоматичних розладів і проблем, пов'язаних із його відносинами в сім'ї, неправильним сприйняттям інформації про ті чи інші методи обстеження або діагностики.

Надання медичної допомоги в контексті суспільства передбачає наявність знання про особливості спільноти, яка оточує пацієнта, що може стати важливим ресурсом при розв'язанні його проблем. Це стосується як особливостей роботи лікаря з урахуванням можливої професіональної шкідливості, так і тих ресурсів, які суспільство може надати. Знання особливостей суспільства, яке оточує пацієнтів, дозволяє не тільки з'ясувати можливі деталі розвитку захворювання, а й залучити допоміжні ресурси для надання допомоги. Координація допомоги $\epsilon$ дуже важливою особливістю загальної лікарської практики. Саме з лікаря загальної практики розпочинається контакт пацієнта з системою охорони здоров'я у цілому. І якщо він буде порадником і адвокатом, який захищає інтереси хворої людини, то процес надання допомоги стане більш ефективним. Відсутність лікаря, до якого можна звернутися з усіма проблемами, призводить до збільшення кількості госпіталізацій і викликів швидкої допомоги, тому що людина почувається незахищеною і безпорадною з розвитком незрозумілих ознак захворювання. У британській літературі нерідко лікаря загальної практики називають воротарем, який може обмежити пацієнту доступ до високотехнологічних і дорогих методів лікування.

Проте роль лікаря загальної практики - сімейної медицини не обмежується тільки доступом до спеціалізованої допомоги, а трансформується у співробітництво лікарів загальної практики з фахівцями, службою швидкої допомоги, працівниками стаціонарів. Це дозволяє більш чітко розв'язувати проблеми пацієнта й економити час і матеріальні ресурси. Така робота дублювання різних методів обстеження при направленні хворого на стаціонарне лікування дозволяє зберегти етапність у веденні пацієнтів із хронічними захворюваннями і підвищує якість надання допомоги. Профілактична спрямованість роботи лікаря загальної практики є одним із найважливіших завдань діяльності в сучасних умовах. Лікар загальної практики, спостерігаючи за своїми пацієнтами протягом їх життєвого циклу, має можливість ідентифікувати фактори ризику розвитку хронічних захворювань. У нього є унікальна можливість займатися первинною профілактикою, пояснюючи пацієнтові правила здорового харчування, важливість фізичної активності, 
шкоду куріння і надмірного вживання алкоголю при будь-якому відвідуванні. Надання допомоги в контексті сім'ї становить неоціненну підтримку для пацієнта з хронічним захворюванням, але і поява хронічного захворювання одного з ії членів може мати серйозний вплив на сім'ю, змінюючи стереотипи, що склалися, стати причиною появи проблем зі здоров'ям у інших ії членів. Залучення членів сім'ї в процес розв'язання проблем пацієнта, пов'язаних із профілактикою або лікуванням, $\epsilon$ потужним ресурсом лікаря загальної практики, що сприяє підвищенню ефективності надання допомоги [12].

У 1991 р. в документі, опублікованому Всесвітньою організацією національних коледжів і академічною асоціацією лікарів загальної практики (WONGA), були сформульовані вимоги, що ставляться до загальної практики. Поряд із координацією допомоги підкреслювався її комплексний характер, що відрізняє загальну практику від інших медичних спеціальностей, тому що включає не тільки лікування, а й профілактику, реабілітацію та зміцнення здоров'я. У цьому документі наголошувалося, що така медична допомога має бути доступною для пацієнтів у будь-який час, а роль лікарів загальної практики повинна полягати не тільки в координації, а й в управлінні розподілом ресурсів охорони здоров'я [13].

Для прискорення переходу до повного охоплення поширення сімейної медицини в Україні можна запропонувати такі регуляторні механізми: забезпечити перехід до організації медичної допомоги населенню за принципом лікаря загальної практики в усіх регіонах країни. Нагальним $є$ питання розробки концепції інтелектуального функціонування системи сімейних лікарів. Необхідне затвердження нової ідеології, центральною ланкою якої $є$ уявлення про сутність сімейного лікаря та передові медичні технології. Витрати на підготовку сімейних лікарів потрібно розглядати як довгострокові інвестиції, а безперервне навчання повинно бути частиною процесу праці та навіть більш важливим, ніж практичний досвід, який швидко втрачає інформаційну цінність. Розробка і втілення технологій лікування, які замінять стаціонарну терапію. Потрібно замінити першість лікарняної системи надання допомоги на амбулаторно-поліклінічні принципи охорони здоров'я, адже кожен ліжко-день обходиться платникам податківу десятки і сотні тисяч гривень, з яких понад 70 \% витрачають на комунальні послуги. Необхідна система донозологічного моніторингу рівня здоров'я з утворенням необхідної структури для сімейних лікарів. Розуміння всього цього процесу має стати для зміцнення охорони здоров'я одним із найважливіших показників.

Одним з основних принципів лікарів загальної практики повинен стати принцип збереження «здоров'я здорових» із введенням диспансеризації сімей сімейної диспансеризації. Оплата праці сімейного лікаря повинна проводитися залежно від прикріплених до нього пацієнтів, а для цього необхідно ввести систему обов'язкового медичного страхування. Кожному лікарю загальної практики у сільській місцевості потрібно дозволити використовувати особистий транспорт із компенсацією палива і забезпечити його засобами зв'язку. Під час перехідного періоду необхідно зберегти поліклініки зі стандартним набором фахівців у містах. Сімейний лікар може виконувати деякі фунції фахівців тільки тоді, коли переконає пацієнтів у своїй компетентносі, а вибирати лікаря буде звичайно пацієнт.

Важливими є принципова зміна системи навчання сімейних лікарів в інтернатурі з введенням самостійної практики в окремих районах і введення комплексного циклу нічних чергувань. Доцільною буде також докорінна зміна програми перепідготовки для педіатрів і терапевтів.

Підготовку сімейних лікарів необхідно проводити не тільки на післядипломному, а й на додипломному етапі. Такий підхід забезпечить краще освоєння практичних навичок, вміння надавати допомогу при невідкладних станах. Для полегшення роботи лікаря загальної практики можна спростити ведення сімейним лікарем обліково-звітної документації. Доцільно зберегти єдиний документ - електронну медичну карту амбулаторного хворого [14].

При роботі з показниками, які характеризують якість і результативність праці лікаря загальної практики, необхідно враховувати кілька обставин. Поперше, з обережністю потрібно ставитися до інтерпретації показників здоров'я (смертність, інвалідність, захворюваність за окремими нозологічними формами). Для статистично невеликих сукупностей отримання того чи іншого негативного результату (смерть, інвалідність) може мати випадковий характер. Надійність, статистична достовірність показників забезпечуються лише при певному обсязі сукупності, за достатньої (з точки зору репрезентативності) чисельності відповідних явищ і населення. По-друге, більшість індикаторів якості медичного обслуговування взаємопов'язана між собою. Найтісніший зв'язок простежується між показниками організації діяльності та показниками здоров'я і якості медичного обслуговування. 
Отже, досягнення певних показників організації роботи є однією з необхідних передумов отримання бажаних кінцевих результатів. Тому показники організації ще називають проміжними, маючи на увазі їх місце у формуванні остаточних показників діяльності лікаря загальної практики. Важливою перевагою їх використання $\epsilon$ можливість оперативного виявлення і розв'язання проблем медичного обслуговування, тим часом як зрушення в показниках здоров'я відбуваються значно повільніше [15].

Висновки. Загальна лікарська практика (сімейна медицина) $є$ унікальною спеціальністю, орієнтованою на розв'язання проблем пацієнта як особистості в контексті його сімейних і соціальних взаємин. Вона

\section{СПИСОК ЛІТЕРАТУРИ}

1. Кашуба Я. М. Аналіз та перспективи розвитку сімейної медицини Львівщини / Я. М. Кашуба, В. Й. Кімакович, М. С. Паєнок. - Львів, 2010. - 47 с.

2. Barker I. Association between continuty of care in general practice and hospital admissions for ambulatory care sensitive conditions : cross sectional study of routinely collected, personal level data / I. Barker, A. Steventon, S. R. Deeny // BMJ. - 2017. - No. 1 (356). - P. 84. doi : 10.1136/ bmj.84.

3. Шкала Л. В. Алгоритм підготовки лікарів загальної практики - сімейної медицини на додипломному етапі навчання / Л.В.Шкала, Г. Ф. Левченко, М.М.Клодченко // Сімейна медицина. - 2007. - № 3 (9). - С. 7.

4. Giezendanner S. General Practitioners' Attitudes towards Essetial Competencies in End-of-Life Care : A CrossSectional Survey / S. Giezendanner, C. Jung, H. R. Banderet // PLos One. - 2017. - No. 12 (2). - P. 0170168. doi : 10.1371/ journal.pone.0170168.

5. Скляров $€$. Я. Громадське здоров'я і громадське медсестринство : підручник / Є. Я. Скляров ; за ред. Є. Я. Склярова, М. Б. Шегедин, Б. Б. Лемішка. - К. : Медицина, 2008. - 224 с.

6. Fichera E. Pay for performance and contractual choice: the case of general practitioners in England / E. Fichera, M. Pezzino // Health Econ. Rev. - 2017. - No. 7 (1). - P. 6. doi:10.1186/s13561-017-0142-x.

7. Деякі питання удосконалення системи охорони здоров'я : Постанова Кабінету Міністрів України від 17.02.2010 р. № 208 // Управління закладами охорони здоров'я. - К., 2010. - С. 69-72.

8. Burkhardt $\mathrm{H}$. Expectations and attitudes concerning geriatric counseling: Results of a survey among general потребує широкого кола знань і вмінь, що включають як навички організації та управління діяльністю, так і консультування пацієнтів із різними проблемами, у тому числі й соціальними. Вміння економічно використовувати ресурси охорони здоров'я та своєчасно призначати науково обґрунтовані методи дослідження, лікування та профілактики може забезпечувати скорочення витрат системи охорони здоров'я у цілому. Історія становлення спеціальності лікаря загальної практики в більшості країн світу демонструє важливість реформування первинної ланки охорони здоров'я за типом загальної практики. Потрібні подальші зусилля, спрямовані на розвиток загальної лікарської практики і підготовку фахівців у цій галузі.

practitioners and hospital-based providers in two German states / H. Burkhardt, C. Trojan // Z. Gerontol. Geriatr. - 2017. doi: 10.1007/s00391-017-1180-z.

9. Білинська М. М. Профілактичне спрямування системи охорони здоров'я: стан та перспективи розвитку / М. М. Білинська, Я. Ф. Радиш, О. В. Худоба // Державна політика у сфері охорони здоров'я. Частина 2 ; за ред. М. М. Білинської, Я. Ф. Радиша. - К. : НАДУ, 2013. C. 221-271.

10. An Overview of the Practitioner Research and Collaboration Initiative (PRACI): a practice-based research network for complementary medicine / A. Steel, D. Sibbritt, J. Schloss [et al.] // BMC Complement Altern Med. - 2017. No. 17 (1). - P. 87. doi: 10.1186/ s12906-017-1609-3.

11. Slovakia: Health System Review / M. Smatana, P. Pazitny, D. Kandilaki [et al.] // Health Syst. Transit.- 2016. No. 18 (6). - P. 1-210.

12. Богатирьова Р. Інформаційно-аналітичні матеріали до парламентських слухань на тему: «Сучасний стан, шляхи і перспективи реформ у сфері охорони здоров'я України» / Р. Богатирьова. - К. : МОЗ України, 2013. - 116 с.

13. Динаміка розвитку сімейної медицини Львівщини / С. М. Федоренко, М. С. Паєнок, Б. Б. Лемішко [та ін.]. Львів, 2011. - 35 с.

14. Зайцев О. М. Інформаційна підтримка лікарів загальної практики - сімейної медицини в сільських районах Харківської області / О. М. Зайцев // Сімейна медицина. - 2011. - № 3. - С. 43.

15. Гиріна О. М. Використання інформаційних технологій в медичній практиці при підготовці сімейного лікаря / О.М.Гиріна // Сімейна медицина. - 2011 - № 3. - С. 14-15.

Отримано 08.02.19 